\title{
Paratextos, ilustración y autoridad en los flores sanctorum castellanos del siglo XVI
}

\author{
Fernando BAÑos VALLEJO \\ Universitat d'Alacant ${ }^{I}$
}

\begin{abstract}
Los paratextos de las sucesivas revisiones del flos sanctorum castellano muestran una intensificación de las estrategias de autoridad, que consisten principalmente en ensalzar la veracidad y la ortodoxia del relato y procurar el amparo de personas e instituciones poderosas. Al comparar los prefacios anteriores y posteriores a Trento, apreciamos un desarrollo notable y una evolución, que pasa de advertir la presencia de pasajes apócrifos a declarar su depuración; los hagiógrafos postridentinos también afirman seguir el elenco oficial de santos, atenerse solo a lo que relatan autores graves, se someten por anticipado a la censura, y dedican sus volúmenes a poderosos. Complementariamente, las ilustraciones preliminares representan los cultos católicos básicos y los vínculos del libro con autoridades e instituciones.
\end{abstract}

Keywords: Paratexto, ilustración, autoridad, flos sanctorum, hagiografía.

Estamos muy lejos de los tiempos en que la hagiografía era la leyenda, la lectura principal, la lectura por antonomasia. Ni siquiera el diccionario de la Real Academia Española recoge ya la definición de leyenda que aún constaba como tercera acepción en la edición de 20oI: 'historia o relación de la vida de uno o más santos'. Tal significado procedía, en efecto, de la condición de lectura principal que tuvo la hagiografía durante la Edad Media y todavía, aunque ya disputada por otros géneros, durante el Siglo de Oro.

Pues bien, no cabe duda de que la modalidad que más contribuyó en toda Europa a la divulgación de las vidas de santos fue el legendario, o compilación de versiones abreviadas, conocida en la Península comoflos sanctorum. Es algo que ya destaqué hace casi treinta años (Baños 1989: 57-58), al tiempo que observaba que aunque la fuente principal de estos santorales fuera la Legenda aurea de Jacobo de Vorágine, en el siglo xvi el flos sanctorum castellano se consolidó en la imprenta con los nombres propios de sus compiladores, como el del fraile jerónimo Pedro de la Vega, y dejó de ser la obra o familia de obras anónima que era en el siglo $\mathrm{XV}^{2}$. Cuando el flos sanctorum se

\footnotetext{
I Trabajo desarrollado en el marco del proyecto de investigación «La hagiografía hispánica ante la Reforma protestante» (FFI2017-86248-P) del Ministerio de Economía, Industria y Competitividad.

2 De todos los testimonios del flos sanctorum castellano anteriores a I500; o sea, de la docena de manuscritos y par de incunables conservados, solamente dos citan la fuente básica. Una, la edición de Juan de Burgos de la Leyenda de los santos, de hacia 1497 (British Library, IB 53312: fol. IIr): «Comienca [sic] la Leyendo [sic] de los sanctos, la qual se llama hystoria lonbarda»,
} 
convirtió en género editorial, se produjeron en él otros cambios, además de la identificación de los nombres de los autores. Si ya en la tradición manuscrita el legendario había dejado de ser un libro exclusivamente conventual, y se podía encontrar en algunas bibliotecas nobiliarias o reales, la imprenta lo exclaustró definitivamente y lo convirtió en un producto comercial cuya fisonomía también cambió, pues pasó de carecer de imágenes a incorporar estampas copiadas de las ediciones europeas (Carvajal y González-Sarasa 20I2: 434-435). He propuesto (Baños 2012: 9I) que, frente a la exclusividad de los lujosos libros de horas, los impresores ofrecieron un producto comercial, los santorales, que se podrían considerar «libros de días», porque en principio estaban ordenados siguiendo el calendario litúrgico para leer la vida del santo de cada día. A la búsqueda de la rentabilidad obedecía la ilustración, que complementaba el texto, pero que por la obligada economía no podía ser iluminación manual y esmerada como la de los libros de horas, sino impresa mediante matrices que se reutilizaban, dentro de un mismo libro, y se pasaban de unas ediciones a otras, incluso de una obra a otra diferente.

Pese a la popularidad de que gozó el flos sanctorum desde su nacimiento en el siglo XIII, y pese a los notables cambios que experimentó en la Edad Moderna, su estudio, y en general el de la hagiografía en prosa, ha ido por detrás de la atención dedicada a las vidas de santos en verso. No obstante, en el siglo XXI estamos avanzando en el conocimiento de esta cadena de reescrituras y en la valoración de que no solo interesan las obras originales, sino también los procesos de actualización. José Aragüés Aldaz (2000) trazó el itinerario de los santorales castellanos del Siglo de Oro a partir de la tradición manuscrita medieval, y en estudios posteriores (Aragüés 2005, 2012 y 2016) precisó la filiación entre las compilaciones medievales y renacentistas.

No nos ocuparemos esta vez del contenido del flos sanctorum en general, ni del conjunto de sus ilustraciones, sino que nos ceñiremos a la función de la palabra y de la imagen en sus paratextos. A este respecto, ya en el primer trabajo de los citados Aragüés (2000:338-345) se percató de la pertinencia de los prólogos y colofones como declaración de la labor de reescritura del flos sanctorum castellano, en cuanto proceso continuo de revisión y corrección. Por mi parte, en mi segunda monografía sobre vidas de santos (Baños 2003: 44-45) destaqué el interés de los prólogos de Alonso de Villegas y Pedro de Ribadeneira, principales autores postridentinos del flos sanctorum castellano, para comprender el cambio de actitud de los hagiógrafos, que se plan-

e Historia lombarda era otro nombre con el que se conocía la Legenda aurea de Vorágine. La otra mención, doble y más precisa, se halla en el rico manuscrito elaborado hacia I 488 para Isabel la Católica, al comienzo de la primera parte: «Aquí comiença el libro que es llamado flor de los santos, que conpuso el honorable varón don Diego de Vorágine»; y de la segunda: «Aquí comiença la segunda parte del libro que es llamado flor de los santos, que fizo Jacobo de Vorágine» (ms. h-II-I8 de la Biblioteca de El Escorial: fols. Ir y CXXIXr). 
tean ya de forma muy expresa el problema de la depuración de lo apócrifo y la cuestión de la autoridad de las fuentes.

Para avanzar en este campo de los paratextos, y en relación con la autoridad, precisamente, procede ahora examinar todo tipo de elementos paratextuales: prólogos y colofones por descontado, pero también portadas, y sobre todo, por más desatendidas, dedicatorias e ilustraciones. Y si bien Claude Chauchadis (2009) ha dedicado un estudio específico a los paratextos del flos sanctorum renacentista, y Aragüés ha reparado en ellos en los trabajos que cito (particularmente 20I4), ambos se centran en las cuestiones mencionadas de la reescritura y la autoría. Parte de los paratextos que ellos han considerado en estas publicaciones, con la suma de otros que por mi lado añadiré, permitirán ofrecer otro enfoque, pues pretendo analizar aquí los paratextos de los flores sanctorum castellanos del siglo XVI no tanto como marcas de autoría, sino como como instrumento de autoridad. Es decir, interesa ahora revisar los recursos utilizados para ganar en credibilidad, más que la reivindicación de una labor que se identifica con nombre propio, aunque ambas nociones están muy relacionadas. Además, en un volumen sobre texto e imagen en el Siglo de Oro procede atender especialmente a la ilustración, también porque es un elemento del flos sanctorum apenas estudiado, como decía arriba, y cuando lo ha sido, el foco se ha puesto sobre imágenes de santos, y no sobre los grabados de los preliminares 3 .

Dado que, según podrá comprobarse, fue a partir del Concilio de Trento (I545-I563) cuando se intensifican en el flos sanctorum las estrategias de autoridad, el método básico que seguiré es comparar los paratextos de los santorales pretridentinos con los postridentinos, porque es en los prólogos, sobre todo, donde se acumulan los recursos para dotar de credibilidad al libro. Otro criterio organizativo será dejar las ilustraciones para el final, porque el previo análisis del argumentario permitirá enmarcar las imágenes en el contexto que nos ayude a comprender su valor. Numeraré correlativamente los fragmentos paratextuales y las imágenes para poder referirme a ellos.

\section{El desarrollo de los prólogos}

Lo primero que se observa al comparar los preliminares de los santorales castellanos desde sus inicios medievales hasta los impresos postridentinos, es el progresivo desarrollo del prohemio, pues se pasa de la carencia absoluta en los manuscritos, con la única excepción que ahora comentaré,

3 Aparte de la atención que los legendarios reciben en estudios generales sobre la ilustración, como el de Lyell (1997), trabajos que se ocupen específicamente de los grabados de flores sanctorum solamente conozco los de Moreno Garrido (198I), Almeida (2009), Baños (2012), Baños (en prensa). El de Civil (1995) trata de la influencia del flos sanctorum en la representación textual y plástica de María. 
a los múltiples y variados paratextos de las sucesivas ediciones de Villegas y Ribadeneira. De la docena de manuscritos medievales, tan solo el preparado para Isabel la Católica traduce el breve prefacio de Vorágine ${ }^{4}$. Se trata de un preámbulo de carácter meramente informativo, pues anuncia el orden de las vidas de santos acorde a los tiempos litúrgicos, que a su vez coinciden con las edades de la Humanidad, las estaciones del año y las partes del día. En términos retóricos es un exordio neutro, porque no enaltece comparativamente la materia, como sí harán los santorales impresos.

El más antiguo de los incunables conservados, El flos santorun con sus ethimologías, impreso entre I472 y I475, carece de prólogo. Pero hacia I493 el impresor burgalés Fadrique de Basilea editó unos preliminares para la Leyenda de los santos, la versión castellana más ligera de la Legenda aurea, frente a la más completa, que conocemos como Flos sanctorum renacentista ${ }^{5}$. Esos preliminares se componen de una Pasión de Cristo, que traduce capítulos del Monotheseron de Juan Gerson, un prólogo de fray Gauberto Fabricio Vagad, cronista de Aragón, y un anteprólogo que posiblemente escribió él mismo, así como pudo ser él también el traductor (Aragüés 2014: 32). En el anteprólogo se citan ambos nombres propios, lo cual es relevante, porque la identificación de los autores es un procedimiento de autoridad. Además, se destaca la operación de anteponer la Pasión de Cristo a las vidas de los santos, lo cual sintoniza con la nueva sensibilidad cristocéntrica del siglo xv; es una manera de conferir credibilidad al santoral, dejar bien claras las jerarquías, explicitar que los santos son caballeros de Dios, soldados de Cristo, seguidores de su estandarte real:

I. E fue acordado que por entrada más principal de todas las sanctidades y excellentes vidas de todos los sanctos se pusiesse luego en el comienço del libro que dellos escrive, que fue nuevamente reconoscido, corregido y emendado, la tan alta en perfeción, de virtud tan desigual y subida, e más que soberana magnanimidad, la muerte y passión del Rey de los reyes y señor de las virtudes Christo Jhesú. E assentose principalmente sobre la cabeça del libro a manera de una illustre soberana y maravillosa cimera de toda virtud. E dévese poner en la mano diestra del que leyere como una pujante, venturosa, magnánima y siempre vencedora seña real de los cavalleros de Dios, que son los sanctos de aquel.

\footnotetext{
4 Véase la nota 2. El hecho de que los legendarios manuscritos sean fragmentarios impide valorar si la carencia de prólogo en los demás es deliberada, pero lo cierto es que, aparte del susodicho, solo hallamos dos vestigios del prefacio de Vorágine en sendos índices, que sin embargo no se corresponden con el contenido de los códices: en el ms. h-III-22 de la Biblioteca de El Escorial y en el ms. 780 de la Biblioteca Nacional de España («de quatro maneras de tiempo»). Véase Hernández Amez (2006).

5 Ambas versiones derivan de sendas tradiciones manuscritas medievales (Aragüés 2005 y 2016).
} 
El único incunable conservado de la Leyenda de los santos presenta un breve prefacio de quince líneas de una columna, que alude, como queda dicho, a la Legenda aurea bajo el otro nombre de Historia lombarda, y que evoca mínimamente el final del prólogo de Vorágine al observar que el libro comienza por las «festividades que corren después del tiempo que fue la ley renovada», etc. Aunque no se especifique el nombre del autor, las alusiones a la fuente suponen también un tímido avance hacia los procedimientos de autoridad. Por otro lado, en ese prefacio se distingue la materia como selecta, acaso por su ortodoxia, frente a otros libros hagiográficos:

2. Comienca [sic] la Leyendo [sic] de los sanctos, la cual se llama Historia lonbarda.[...] Empero común e vulgarmente se llama flos sanctorum, porque aquí no están así por entero las vidas e historias de los sanctos, como en el Vitas Patrum, mas está lo más escogido e la flor de cada vida.

La siguiente edición que conservamos de la Leyenda de los santos (Sevilla, Varela, I520-I52I), se presenta en su portada con un incremento de autoridad: «agora de nuevo empremida, y con gran estudio y diligencia extendida y declarada, y a la perfeción de la verdad traída».

La primera edición (Zaragoza, Cocci, I5I6) de la otra versión castellana de la Legenda aurea, la que conocemos como Flos sanctorum renacentista, fue preparada por un anónimo fraile jerónimo, siguiendo el trabajo de otro jerónimo del siglo xv, fray Gonzalo de Ocaña, según indica el colofón. Podría muy bien ser Pedro de la Vega, que queda identificado como compilador en ediciones posteriores (Chauchadis 2009: 3I2; Aragüés 20I4: 28). El primer prólogo, además de aludir a Gonzalo de Ocaña como compilador inicial, identifica a Vorágine como autor de la fuente principal en términos que recuerdan los del manuscrito elaborado para Isabel la Católica probablemente en el monasterio jerónimo de Guadalupe ${ }^{6}$. Ese primer prólogo, por otro lado, redunda en la imagen que ya hemos visto en los preliminares de la Leyenda de los santos, los santos como soldados de Dios, cuyos triunfos sobrepujan en heroísmo a los de los caballeros; además, las historias de los santos son «verdadera relación», frente a los libros de caballerías y demás literatura seglar, que son «fablillas de los poetas». Es la primera vez que en el prólogo de un santoral se afirma la veracidad, en este caso frente a la ficción:

3. [...] se compuso y ordenó el presente libro: porque enseñados por su leción los mortales, deprendan alabar a Dios e poner en Él toda su esperança, e no

6 Al final del primer prólogo: «mayormente de la copilación que hizo de las vidas de los santos el muy honorable e sabio varón fray Jacobo de Vorágines, de la Orden de Predicadores, arçobispo de Génova». Para la vinculación del manuscrito de la reina con el scriptorium de Guadalupe, véase Baños (2009: 174-175). 
olvidar sus beneficios, mas buscar siempre e inquirir sus mandamientos e complirlos por obra. E si para el fin susodicho fueron con tanta diligencia las sanctas historias escriptas por los padres antiguos, cuánto son dignos de reprehensión los que (dexada aparte e postpuesta la leción deste libro) se ocupan de todo su coraçón en los tratados vanos e seglares, e llenos de fablillas de los poetas. (...) Pues si te deleitan los hechos maravillosos e por la mayor parte fingidos de los esforçados cavalleros, que puestos en las batallas no supieron bolver las espaldas, lee en este libro e verás los triunfos muy gloriosos de los apóstoles, que con solas las armas de su fe vencieron todo el mundo. Rebuelve estas historias e sabrás por su muy verdadera relación cómo los santos mártires puestos en la batalla de los tormentos antes les faltó la vida que el esfuerço.

\section{Cautela con la materia apócrifa / autocensura}

El segundo prólogo de esa misma edición nos ofrece otra dicotomía básica relacionada con la verdad, que se irá incrementando en los paratextos posteriores como reclamo de credibilidad: los relatos verdaderos frente a los apócrifos (Chauchadis 2009: 3II). Así:

4. E avisamos a los lectores deste libro que no se escandalize ni offenda su claro juizio si en algunas historias hallaren scripto alguna cosa que les parezca menos digna de crédito, e sepan que no las posimos (como dizen) de nuestra cabeça, mas por esto solo las dexamos passar: porque assí las hallamos en los libros antigos. E cuando en algunas de las historias alguna cosa tal se offreciere, usaremos desta cautela: que en ellas mesmas se notará por apócrifo lo que assí pareciere menos digno de fe, porque en esta manera sepan los lectores apartar lo dudoso de lo verdadero.

Una diferencia sustancial que se aprecia entre los santorales anteriores y posteriores a Trento es, precisamente, la actitud hacia lo apócrifo. Para facilitar la lectura fluida de los paratextos de Villegas y Ribadeneira, y para evitar reiteraciones de las citas como evidencias de las diferentes estrategias de autoridad, transcribiré seguidos en un apéndice los extractos correspondientes. A él y a su numeración remito para la comprobación de las observaciones que voy planteando.

En el aspecto que ahora nos ocupa de la actitud hacia lo apócrifo, la diferencia es que si al anónimo autor del flos sanctorum de 1516 le parecía suficiente marcar como dudosos los pasajes en cuestión (lo cual ya hacía en el siglo XIII el propio Vorágine), pero los preservaba, porque estaban «en los libros antiguos», después de la ruptura protestante y después de Trento, los hagiógrafos ya no se conforman con la advertencia, sino que declaran en los paratextos su intención de depurarlos. Todavía durante la celebración del 
concilio, fray Martín de Lilio publica una revisión del Flos sanctorum renacentista (I558) en cuyo colofón se advierte: «corregido y emendado de muchas cosas apócrifas y otras sospechosas en la fe», condición que se destaca ya en la portada y en las tablas: «de muchos errores purgado» y «alimpiado» (Chauchadis 2009: 3I6). Villegas afirma en la dedicatoria a Felipe II (6), que en los flores sanctorum anteriores «se leen muchas cosas apócrifas, y agenas de toda verdad», y en el segundo prólogo (8): «Y lo mismo digo acerca de los milagros, que escreví los ciertos, y dexé los dudosos». Y Ribadeneira en el prólogo (13: 7-8): «dexaré algunas cosas, que aunque estén muy recebidas entre la gente común, no me parece que están tan bien fundadas, ni con tanta autoridad, que yo las pueda afirmar». Estas son sus declaraciones de intención, pero lo cierto es que en las vidas mantienen muchos pasajes que a los ojos no ya de un escéptico, sino incluso de un creyente, pueden parecer también dudosos. Pero no cabe aquí un examen minucioso de los episodios apócrifos, que llevaremos a cabo en futuras investigaciones.

\section{Elenco oficial de santos}

Específicamente postridentino es el planteamiento de qué santos deben incluirse en la compilación; lo que podríamos llamar el santoral canónico. La posición de Villegas y Ribadeneira es común, y es también una consecuencia de la Reforma protestante, pues declaran que se ciñen al Breviario romano reformado por decreto del Concilio de Trento (5, 6 y I3: 7-8). Buscan con ello el respaldo a sus obras de la más alta autoridad de la Iglesia católica. Ello implicaría excluir a los santos extravagantes, llamados así precisamente por no formar parte del Breviario romano, pero la verdad es que también en esta selección, como en la de los pasajes auténticos, caen en cierta contradicción, porque uno y otro se permiten concesiones en el elenco de santos. Villegas anuncia: «Y porque nada en él faltasse, puse al fin dél algunas vidas de santos extravagantes», y algo similar Ribadeneira en su prólogo (I3: 7-8).

La cuestión del elenco oficial guarda relación con la afirmación del culto a los santos que estableció el Concilio de Trento en reacción a las críticas protestantes. En este contexto, Villegas sintoniza con Roma al considerar herética la traducción de la Biblia, y sin embargo defiende la divulgación de las vidas de santos (II: 5c), porque son instrumento para llegar a Dios, a modo de gafas para verlo, y «cada santo es como un Evangelio vivo», y en cambio «la erudición y pericia de la Escriptura puede hazer a uno buen theólogo, y no buen christiano» (II: 5a-5b); y Ribadeneira (I3: 2-3) afirma que las vidas de santos son «martillo y cuchillo contra los hereges», y, además, que constituyen la interpretación de las Escrituras, según cita de san Jerónimo. 


\section{Fuentes autorizadas}

En estos mismos preliminares Villegas y Ribadeneira se esfuerzan en la construcción de autoridad mediante la insistencia en el uso de fuentes autorizadas. No les sirve, como al anónimo jerónimo de 1516 (4), encontrarse su materia en libros antiguos, sino que proclaman la excelencia de sus fuentes (7: 6), que son básicamente Luis Lipomano, obispo de Verona, y Lorenzo Surio, monje cartujo, «dignos de perpetua alabança e recordación», como dice Ribadeneira en su prólogo (I6I6: 7). Pero tanto él como Villegas conectan estas fuentes concretas con la consolidada historiografía de la Iglesia, de manera que afirman repetidamente que se ciñen a lo relatado por autores graves $(6,7: 6,8,13: 7-8)$. Por cierto, que ni uno ni otro incluyen entre ellos a Vorágine.

Podríamos decir que en los legendarios postridentinos emerge la categoría de «autor grave», frente a la autoridad indiscriminada y más relativa de la mera fuente escrita, cualquiera que esta sea, que era un planteamiento más propio de la Edad Media. En consecuencia, distinguiríamos dos categorías de lo apócrifo: lo falso, y otra más sutil, lo que carece de autoridad contrastada. Así, Villegas (6) diferencia: «se leen muchas cosas apócrifas, y agenas de toda verdad, léense también otras muchas tan faltas de la autoridad y gravedad». Y Ribadeneira enseña que no es suficiente credibilidad la mera transmisión de un relato; recordemos: «aunque estén muy recebidas entre la gente común, no me parece que están tan bien fundadas, ni con tanta autoridad» (13: 7-8).

\section{Aceptación previa de eventuales censuras}

Otro procedimiento de legitimación es prevenirse contra posibles errores. Ya Pedro de la Vega, en su revisión de I52I, al comienzo de las tensiones contrarreformistas, da muestra fugaz de la actitud de sometimiento a la autoridad de la Iglesia Romana y aceptación anticipada de cualquier corrección: «demando perdón a los lectores sometiéndome a la corrección de la Iglesia» (Chauchadis 2009: 313). Después de Trento, Villegas será bastante más explícito:

Y si alguna cláusula o sentencia aquí se hallare, que por tener diversos sentidos, alguno dellos fuere erróneo, o sospechoso, digo que mi intento fue dezirlo a sentido católico, y no otro. Digo más: que [...] me sujeto a la corrección y censura de la santa madre Iglesia Romana (7: 8). 
En todo caso, los libros impresos en España en la segunda mitad del XVI suelen llevar, como en efecto llevan los de Villegas, licencia y aprobación del censor eclesiástico.

\section{Dedicatorias}

Ya Pierre Civil (1997: 87) y Aragüés (2005: 130) se fijaron en la dedicatoria que Villegas ofrece a Felipe II (6). Comienza por halagar al rey atribuyéndole el impulso necesario para que se hayan impuesto en España el Misal y el Breviario romanos que dimanan del Concilio de Trento. Ruega al monarca que apoye ahora la reforma del flos sanctorum, una vez consolidado el Breviario romano. El hagiógrafo defiende la necesidad de la revisión del legendario, porque los anteriores, por sus elementos apócrifos y su falta de autoridad, «antes provocan a irrisión que a devoción, las cuales dan bastante causa a gentes de otras naciones para que burlen de los españoles» (6). Y parece que Villegas no pensaba solo en las burlas de los protestantes, sino que da a entender que incluso los católicos extranjeros podrían mofarse de la baja calidad del santoral castellano, situación que él pretende solucionar con el libro que ofrece al rey. Reclama para sí la honra de haber redactado el tan necesario flos sanctorum reformado; el adjetivo lo dice todo: «Por lo cual con la censura y licencia de Vuestra Majestad podrá tener nombre de Flos sanctorum reformado» (6).

Apreciamos así que dedicar el libro a algún poderoso es otra manera de conferirle autoridad, más allá de protegerlo y protegerse. Si el primer volumen Villegas se lo dedica al rey, el segundo (Io) lo dirige al Inquisidor General y cardenal Gaspar de Quiroga, Arzobispo de Toledo y Primado, es decir, máxima autoridad de la Iglesia en España. Con ello viene a completar los ámbitos de protección y autoridad, puesto que abarca el poder civil y el eclesiástico en sus más altos rangos, un enroque perfecto. Por su parte Ribadeneira (I2), que fue un destacado jesuita, dedica su flos sanctorum a la reina Margarita de Austria, esposa de Felipe III. Cabe recordar que la reina confió su dirección espiritual a los jesuitas, y que favoreció mucho a la orden, en cuyo patrocinio coincidió con el de la emperatriz María de Austria, durante su vida en Madrid y antes. La hija de esta, por otro lado, la infanta sor Margarita, monja en las Descalzas de Madrid, es la dedicataria del libro de Ribadeneira sobre los santos extravagantes (24).

\section{El complemento de las imágenes}

Y vamos con la última parte, no menor: las ilustraciones también cumplen la función de conferir autoridad, y en esto son solidarias con los textos. 
Si reparamos en las imágenes que hemos incluido en el apéndice II, se puede comparar el uso que se hace de las divisas nobiliarias o reales en un par de manuscritos castellanos del flos sanctorum con el que tienen en las ediciones.

El manuscrito de la primera mitad del siglo XV (I4) muestra una capital iluminada (una T, parece) con el escudo del Conde de Haro, y en el margen inferior la cruz de san Andrés, otra divisa de los Velasco. Son signos que funcionan como un ex libris que identifica el ejemplar como propiedad de Pedro Fernández de Velasco, primer Conde de Haro. Similar uso de las enseñas apreciamos en el flos sanctorum de hacia I488 (I5), elaborado para la biblioteca de Isabel la Católica: el escudo de los Reyes Católicos representa en este caso a Isabel, porque va sobre el águila de san Juan (que es divisa suya) y porque carece del yugo de Fernando; además la divisa del margen derecho, los haces de flechas, es específica de la Reina, y lleva la inscripción «Regine digne», que no es otra cosa que un ex libris: «De la Reina digna» o «justa»7. Estos son códices únicos y «personalizados», muy diferentes en ello del producto en serie que genera la imprenta, claro está, pero hay elementos nuevos y distintos en el flos sanctorum elaborado para Isabel la Católica, seguramente en el scriptorium del jerónimo monasterio de Guadalupe, que anticipan las estrategias de autoridad que en el siglo Xvi consolidarán los legendarios impresos. Una de ellas, que ya he tenido ocasión de poner de relieve (Baños 2009: I77), consiste en anteponer la Vida de Cristo a las vidas de santos, con lo cual se señala debidamente la jerarquía, como queda dicho. Ello es precedente de lo que se consolidará en el Flos sanctorum renacentista, la organización de los capítulos en dos secciones, la relativa a Cristo y la de los santos, rompiendo el ciclo litúrgico único (Aragüés 2005: I46); o de la operación análoga de la Leyenda de los santos impresa, la anteposición de una Pasión de Cristo. La otra innovación, ya indicada arriba (nota I), consiste en identificar, por primera y única vez en la tradición medieval castellana, el nombre del autor de la fuente, al tiempo que se pondera su dignidad: «Aquí comiença el libro que es llamado flor de los santos, que conpuso el honorable varón don Diego de Vorágine». Esa identificación se produce al comienzo de la primera parte sobre la Vida de Cristo y se repite en la segunda, que contiene las vidas de santos (fols. Ir y CXXIXr), en sendas rúbricas destacadas en tinta roja.

Pues bien, igualmente, las primeras ilustraciones en los preámbulos de los santorales castellanos representan la preeminencia de Cristo: así, los preliminares para la Leyenda de los santos muestran un calvario complementado con los símbolos de los cuatro evangelistas (I6), y esta pauta la sigue la edición renacentista (I8), en una versión más simple que carece de los símbolos

7 Véanse Baños (2009 y 20I0) para más información sobre ejemplares del flos sanctorum castellano vinculados de alguna forma a la nobleza o la realeza. 
de los evangelistas. Ambos impresos sitúan la ilustración inicial en el vuelto de la portada. La otra versión castellana, el Flos sanctorum renacentista, ubica en la portada misma de su primera edición un rico grabado (I7), cuya belleza y complejidad ya señaló Aragüés (2005: II5). La imagen principal es de nuevo el calvario con los símbolos de los cuatro evangelistas, pero ofrece otra treintena de imágenes de apóstoles, mártires, confesores y vírgenes, como reza el título. Pero el título, precisamente, empieza por mencionar las secciones dedicadas a Jesús y a la Virgen. De este modo, título e ilustraciones son coherentes en unir los relatos crísticos, marianos y hagiográficos, marcando, eso sí, las diferencias de rango. Es una portada en la que se realiza una verdadera síntesis de cultos, en texto y en imagen. Además, la portada se complementa con siete leyendas en latín, que enaltecen los méritos de los diferentes tipos de santos.

En esta ocasión nos ceñimos a las ilustraciones de los preliminares, y no tratamos las que acompañan los sucesivos relatos; con ese enfoque se aprecia un desarrollo notable en el uso de imágenes en los preámbulos de los santorales postridentinos. Si tomamos como muestra el primer volumen del flos sanctorum de Villegas, percibimos diferentes propósitos, que tienen en común la afirmación de la autoridad: la doctrinal en la portada, pues representa a Cristo triunfante en su descenso a los infiernos, liberación de los justos y salutación de los santos patriarcas y profetas a María (I9). Esta ilustración sigue la línea de las tres anteriores, pero las restantes de los preliminares de esta edición la vinculan con personas que confieren autoridad. La mencionada dedicatoria de Villegas a Felipe II (20) lleva la divisa del rey, casi como si el libro fuera suyo. Páginas más abajo, después del prólogo al lector, hay una imagen que sirve de sello de autentificación (2I), algo que ya señalaron Civil (I997: 84) y Aragüés (20I4: 37). Villegas advierte: «cualquiera de las partes deste Flos sanctorum donde no se hallare este mismo [retrato], y no otro contrahecho por él, que no se tenga por mía; antes devría evitarse como sospechosa». Solo él puede garantizar la autenticidad de la edición del «Flos sanctorum reformado», aunque con «la censura y licencia» del rey (6), y con la «censura de la santa madre Iglesia Romana» (7: 8).

La edición del segundo volumen lleva en su portada otro retrato (22), que parece ser el del Inquisidor General y máxima autoridad de la Iglesia en España, don Gaspar de Quiroga. Así que el primer volumen queda bajo el amparo del rey, y el segundo bajo la protección del Primado de España. Se hace evidente el diferente uso de los emblemas o retratos que representan a personas, casas o instituciones en los manuscritos, donde funcionaban como ex libris, y en los santorales postridentinos, en los que sirven como instrumento de autoridad.

También la vinculación y el amparo se pueden buscar en una orden religiosa, como es el caso de los volúmenes de Ribadeneira (23 y 24) y los jesui- 
tas. En la portada del volumen primero (23) aparece el emblema de la Compañía de Jesús (el monograma IHS inscrito en un sol radiante, con los tres clavos de la Pasión unidos en sus puntas), enmarcado en los cuatro evangelistas. En el libro de Extravagantes se funde el emblema de la Compañía con el águila bicéfala y corona imperial de la casa de Austria, y un lema: «Tenui eum nec dimittam» ('lo así y no lo soltaré'), del Cantar de los cantares $(3,4)$. La misma estampa, incluido el lema, la había utilizado el impresor un año antes en un libro que la Compañía de Jesús publicó para honrar la memoria de la emperatriz ${ }^{8}$, madre de sor Margarita, dedicataria de estos dos libros, para lo que no obstó que ella fuera clarisa. De modo que puede concluirse que el flos sanctorum de Ribadeneira, tanto por el propio autor como por las dedicatarias de su obra y por los posteriores revisores (Juan Eusebio Nieremberg y Francisco García), es un santoral del ámbito jesuita, de la misma manera que el Flos sanctorum renacentista lo era del ámbito jerónimo. Entre los siglos XV y XVII el gran flos sanctorum castellano sigue ese itinerario que va de los jerónimos a los jesuitas, en paralelo a la competencia entre órdenes por influir sobre la casa real, una proximidad que tras la muerte de Felipe II será declinante para los jerónimos y creciente para los jesuitas9.

En conclusión, las ilustraciones de los preámbulos de los legendarios muestran un desarrollo análogo al de los textos preliminares, y tanto la retórica como la imagen obedecen a consolidar la credibilidad del contenido del libro. Como reacción a las críticas que los reformistas vertieron sobre las vidas de santos, y después de la afirmación de este culto en el Concilio de Trento, los hagiógrafos ya no se conformaban con advertir de lo dudoso de algún pasaje, sino que declaraban su intención de purgar lo que no estuviera autorizado por autores graves. Además, Villegas y Ribadeneira se valen de los prefacios para afirmar la corrección de su obra: por un lado citan sus fuentes generales, y por otro declaran expresamente su ortodoxia, como cuando dicen ceñirse a los santos incluidos en el Breviario romano reformado, o manifiestan de forma explícita que se someten a cualquier censura que pudiera provenir de la Iglesia católica, se desmarcan de los protestantes y, como refuerzo y defensa de todo ello, dedican su libro a poderosos de la Iglesia o a miembros de la casa real, incluso al mismo rey. Las estampas, además, representan gráficamente los vínculos del flos sanctorum con el Salvador y el poder celestial, y con las autoridades del poder terrenal, en todos sus ámbitos. Palabra e imagen construyen una autoridad más sólida que nunca.

8 Es el Libro de las honras que hizo el Colegio de la Compañía de Jesús de Madrid, a la M. C. de la Emperatriz doña María de Austria, fundadora del dicho Colegio, Madrid, Luis Sánchez, I603, p. 46. 9 Recordemos que el propio Ribadeneira había dedicado en 1595 al futuro Felipe III un Príncipe cristiano, en el que defendía, contra Maquiavelo, que el gobernante ha de regirse por las virtudes cristianas. 


\section{Apéndice I: Paratextos de Villegas y Ribadeneira}

5. Del primer volumen del Flos sanctorum de Villegas, que se titula Flos sanctorum y historia general de la vida y hechos de Jesuchristo, Dios y Señor nuestro, y de todos los Santos de que reza y haze fiesta la Iglesia Católica, conforme al Breviario Romano, reformado por decreto del Santo Concilio Tridentino:

\section{Dedicatoria a Felipe II}

[...] en el santo Concilio Tridentino. De donde resultó que el papa Pío V, de felice memoria, puso diligencia en que el Missal y Breviario Romano antiguo se reformassen, y reformados, se usassen y recibiessen en toda la Iglesia Católica, como se vee que se ha hecho. Aunque en España con dificultad se recibieran, por la afición grande que cada obispado tenía a su oficio y estilo propio, si V. M. inspirado (según se puede y debe creer) por Dios, no lo huviera tomado tan de propósito [...]. Quédale ahora a vuestra M. otra cosa que mandar, no menos importante y necessaria en su razón: y es se reforme el Flos sanctorum, libro donde están las historias y vidas de los santos, de que en el oficio divino se haze mención. Porque dexando aparte que en los libros deste nombre que ahora andan, se leen muchas cosas apócrifas, y agenas de toda verdad, léense también otras muchas tan faltas de la autoridad y gravedad que pide semejante letura, que antes provocan a irrisión que a devoción, las cuales dan bastante causa a gentes de otras naciones para que burlen de los españoles, porque en su lengua no tienen cosa grave y de autoridad, en materia de tanta importancia. [...] visto que el Breviario reformado se ha recebido en España, procuré poner en orden lo que tenía allegado, y juntarlo todo en un volumen y libro, donde se verá lo primero la vida de Christo nuestro redemptor, y luego todas las fiestas y solennidades, assí del mismo Jesuchristo, Dios y Señor nuestro, y de su sacratíssima Madre, y de todos los santos de quien reza y haze mención el Breviario reformado, como también las fiestas que se celebran en España a santos particulares, naturales della. Y porque nada en él faltasse, puse al fin dél algunas vidas de santos extravagantes. Todo lo cual colegí de autores graves y fidedignos. Por lo cual con la censura y licencia de V. M. podrá tener nombre de Flos sanctorum reformado.

\section{Primer prólogo al lector}

[...] Y si la historia en común trae al mundo tan importante provecho, cuánto mayor y más importante le traerá la historia particular de vidas de santos. (I) [...] Assí que en la historia de vidas de santos, no solamente hallará medicina y remedio uno para un solo vicio, y exemplo para una sola virtud; mas todos hallarán remedio para todos los vicios, y todos tendrán exemplo de todas las virtudes (2).

[...] De los autores y lugares que he referido, todos muy graves, muy auténticos y verdaderos, recoligieron y compusieron sus grandes volúmenes, el dotíssimo obispo Lippomano, y el religiosissímo y no menos elocuente y erudi- 
to fray Laurencio Surio, y de los mismos he yo sacado lo que en este libro he puesto, aunque en diferente manera [...]. Y porque mi intento fue escribir de todas las solennidades y fiestas que celebra la Iglesia, conforme al Breviario reformado, hecho por orden del Concilio Tridentino (6).

[...] Y si alguna cláusula o sentencia aquí se hallare, que por tener diversos sentidos, alguno dellos fuere erróneo, o sospechoso, digo que mi intento fue dezirlo a sentido católico, y no otro. Digo más: que assí en esto que aquí en este libro he escrito, como en todo lo demás que por escrito, o en público, o en otra cualquier manera he dicho, o dixere, he escrito, o escriviere, me sujeto a la corrección y censura de la santa madre Iglesia Romana, y de su cabeça, que es el Summo Pontífice, y de todos sus fieles ministros, y que estoy apercibido para me corregir siempre que me sea dicho, lo en que yo, como hombre, aya errado (8).

\section{Segundo prólogo al lector}

[...] De otra cosa también temo que me han de culpar algunos, y es aver dexado de escrevir algunas cosas muy recebidas en vidas de santos. A lo cual digo que si las dexé de escrevir, fue por no averlas hallado en autor grave y auténtico [...]. Yo solo pretendí escrevir lo que pude autorizar con autor o escritura auténtica y grave. Y lo mismo digo acerca de los milagros, que escreví los ciertos, y dexé los dudosos (70v).

9. Del segundo volumen del Flos sanctorum de Villegas, titulado Flos sanctorum. Segunda parte y historia general en que se escrive la vida de la Virgen sacratíssima madre de Dios y Señora nuestra, y las de los sanctos antiguos que fueron antes de la venida de nuestro Salvador al mundo:

\section{Io. Dedicatoria}

Al illustrísimo señor don Gaspar de Quiroga, cardenal de la sancta Iglesia de Roma, arçobispo de Toledo, Primado de las Españas, Chanciller mayor de Castilla, Inquisidor General y del Consejo de Estado de su Magestad.

\section{Prólogo al lector}

La erudición y pericia de la Escriptura puede hazer a uno buen theólogo, y no buen christiano, si no obra lo que sabe: para esto aprovecha en gran manera leer y meditar en las vidas de los sanctos, que son dechado en que está dibuxada la arte de la christiandad; y cada sancto es como un Evangelio vivo. [...] Son los sanctos antojos ['gafas'] claros y christalinos, hannos de servir de medio para ir a Dios favoreciéndonos de sus méritos, intercessiones y ruegos, imitándolos, y juntamente con esto honrándolos y reverenciándolos, aunque no con la reverencia y honra devida a Dios (5a-5b).

[...] A esto digo que sanctíssimamente y con acuerdo del Cielo está manda- 
do que la Sagrada Escriptura y Biblia no ande en lengua vulgar, y aunque otro inconveniente no oviera, sino por ser pretensión de algunos hereges de nuestros siglos de que todas las gentes y naciones tengan la Biblia en su lengua, era bien se vedasse; mas también entiendo que conviene que las vidas de los sanctos de que hazen mención la Sagrada Escriptura sean de todos enteramente sabidas $(5 \mathrm{c})$.

I2. De Ribadeneira, Flos sanctorum, o libro de las vidas de los santos, escrito por el padre Pedro de Ribadeneira, de la Compañía de Jesús, natural de Toledo. Dirigido a la reina de España doña Margarita de Austria. Primera parte:

\section{I3. Prólogo al lector}

Es assí mismo de grandíssima gloria para toda la Iglesia católica, saberse los innumerables y esclarecidos hijos que ha tenido. [...] Demás desto, es un fuerte escudo y defensa contra los infieles que la contrastan, y un martillo y cuchillo contra los hereges, cuyos errores y desatinos con ninguna cosa se convencen mejor que con los exemplos de los santos. Porque es más excelente modo de enseñar con obras que con palabras, y las obras de los santos son santas, y contrarias en todo y por todo a los disparates y desvaríos de los hereges. Y assí para convencerlos e interpretar las cosas dudosas y lugares difíciles de las divinas letras es gran luz la vida y exemplos de los santos, que por esto dixo san Gerónimo: «Vita sanctorum, interpretatio est Scripturarum» (2-3).

[...] Porque en las historias de los santos ay muchas cosas escuras y enmarañadas, que se han de desmarañar y esclarecer [...] otras por una parte apócrifas, y por otra tan recebidas y assentadas en la común opinión, que ni se pueden aprovar sin notable perjuizio de la verdad, ni desechar, sin grave ofensión de la gente vulgar y común. [...] Y si se quieren acortar, muchas vezes se escoge más lo que admira que lo que edifica, y más los milagros que las virtudes (4).

[...] Y porque no es mi intento principal en esta historia abarcar ni referir todo lo que está escrito de los santos, sino escoger y entresacar las cosas ciertas y averiguadas, y las que más nos puedan mover a la imitación de los mismos santos, cuyas vidas escrivimos, dexaré algunas cosas, que aunque estén muy recebidas entre la gente común, no me parece que están tan bien fundadas, ni con tanta autoridad, que yo las pueda afirmar. [...] En este Flos sanctorum van las vidas de los santos que celebra la Iglesia romana, y de quien reza en su Breviario, porque de los otros santos que no están en él, y son extravagantes, he escrito e impresso otro tomo. Y por escrivirse este libro en el Arçobispado de Toledo, he añadido las fiestas de los santos que se celebran en él, aunque no son universales, ni de todas las iglesias de España. He puesto al principio la vida de Christo nuestro Salvador, porque es fuente, raíz y causa de toda santidad, y autor y glorificador de todos los santos; y la Reina del Cielo Nuestra Señora, su benditíssima Madre (7-8). 


\section{Apéndice II: Ilustraciones de flores sanctorum castellanos}

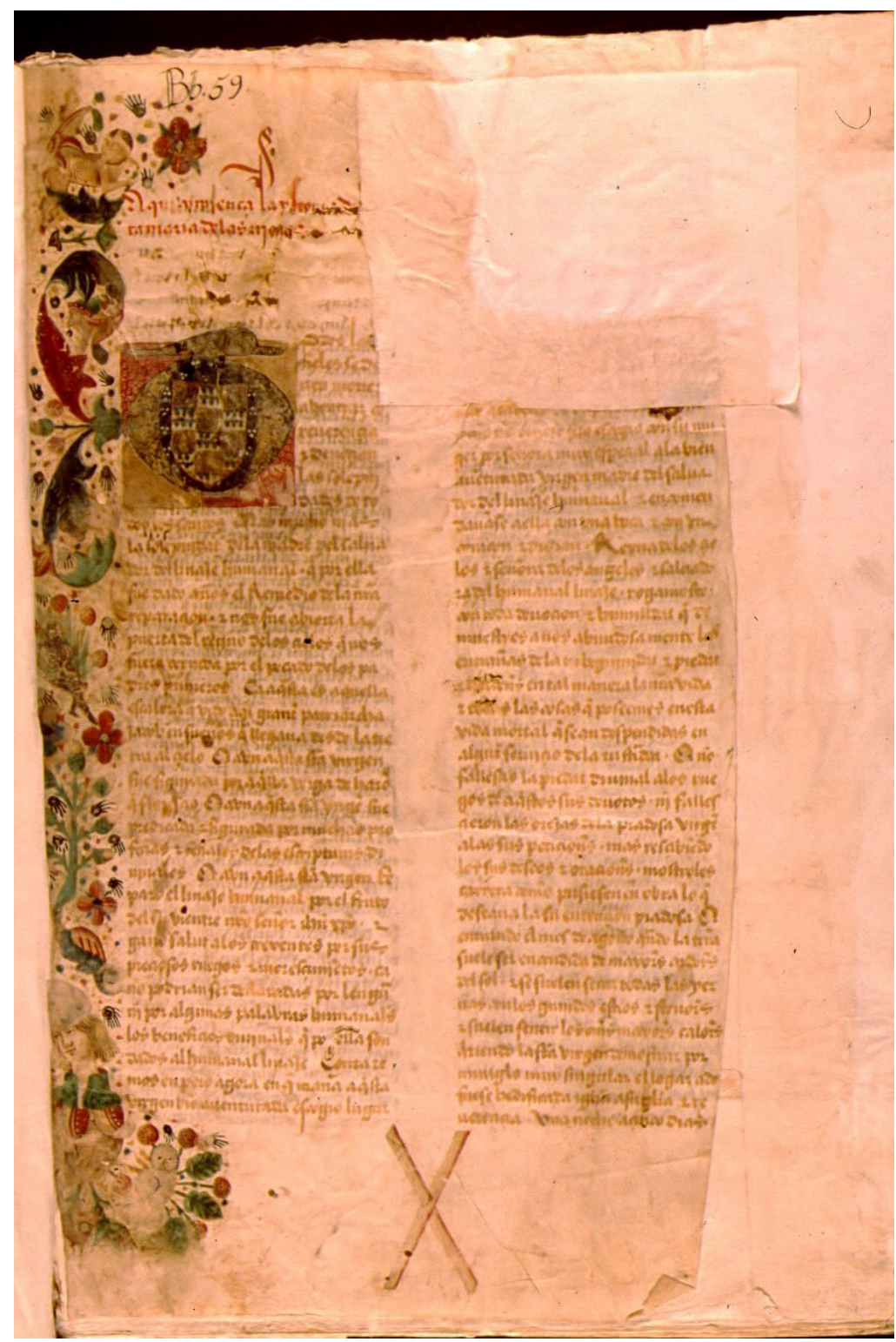

I4. Flos sanctorum copiado para Pedro Fernández de Velasco, primer Conde de Haro. Ms. 12689 de la BNE, fol. Ir. Primera mitad del siglo xv. 


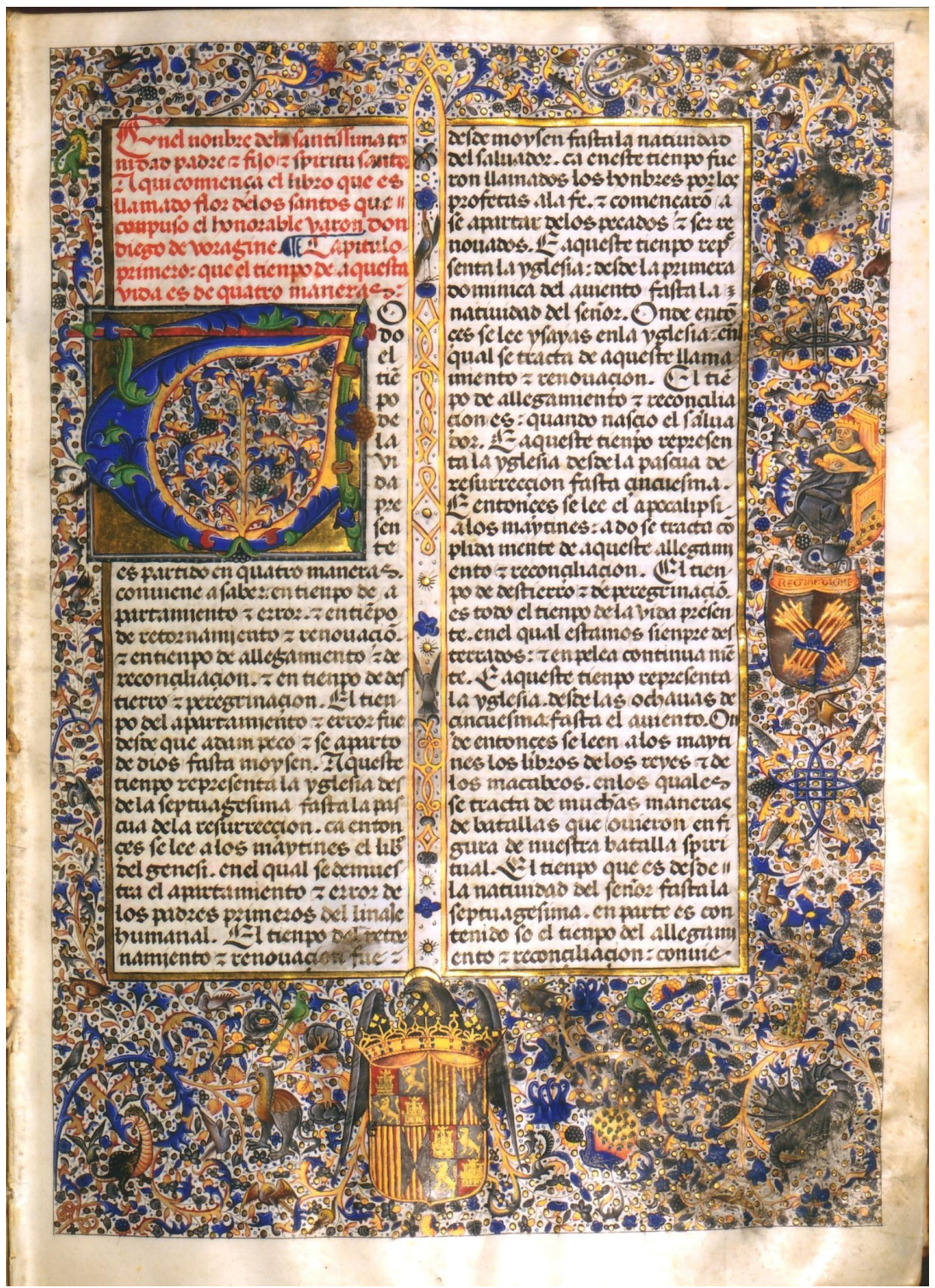

I5. Flos sanctorum copiado para Isabel la Católica. Ms. h-II-I8 de la Biblioteca de El Escorial, fol. Ir. Ca. 1488 . 


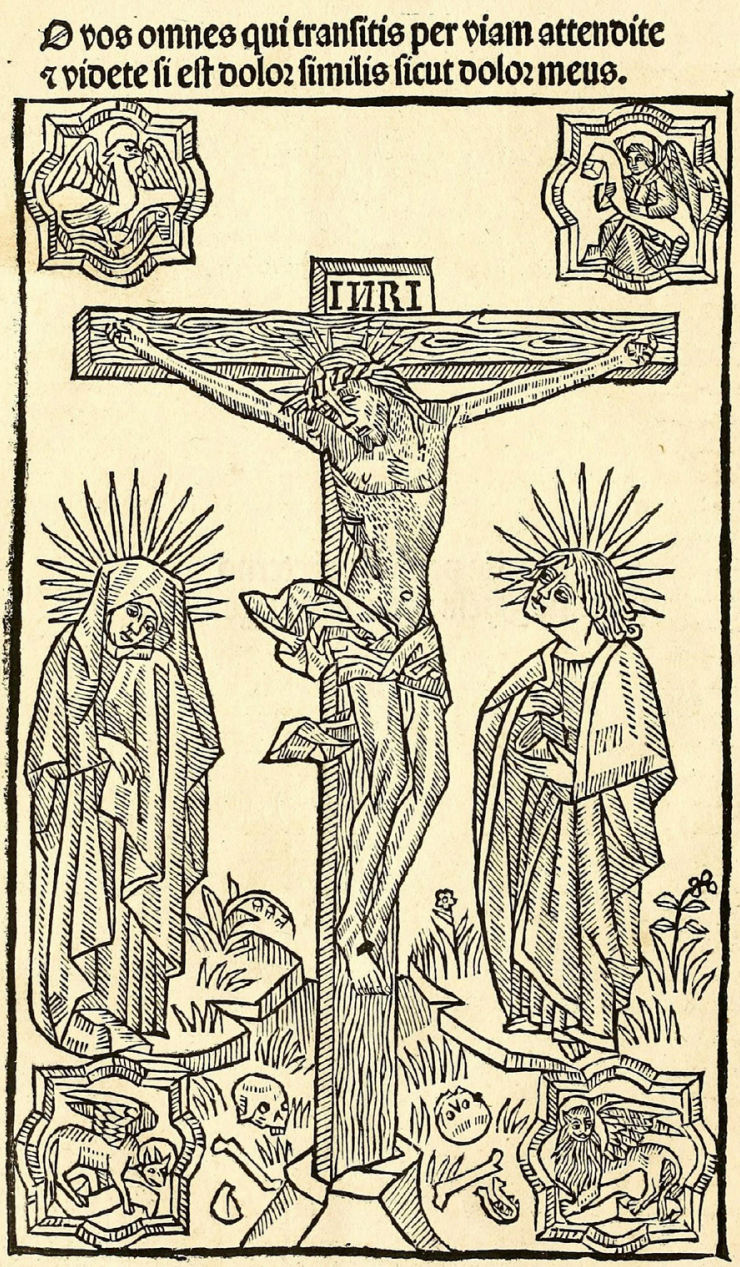

I6. Preliminares a la Leyenda de los santos. Burgos, Fadrique de Basilea, I493 (?). Boston Public Library, Q.403.88, fol. Iv. 


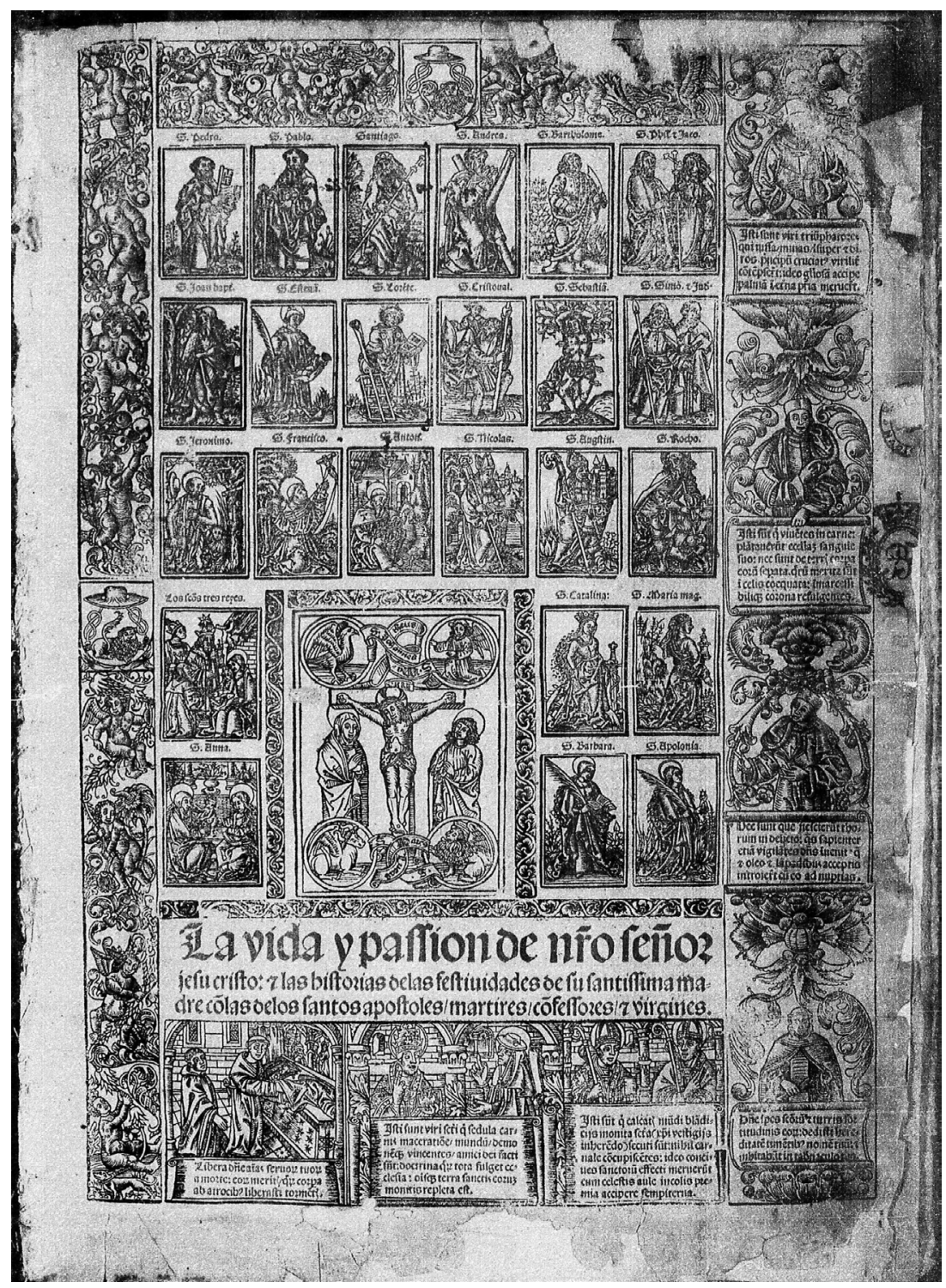

I7. Flos sanctorum, Zaragoza, Jorge Cocci, 1516. Biblioteca Nacional de España (Madrid), R-23859, portada. 


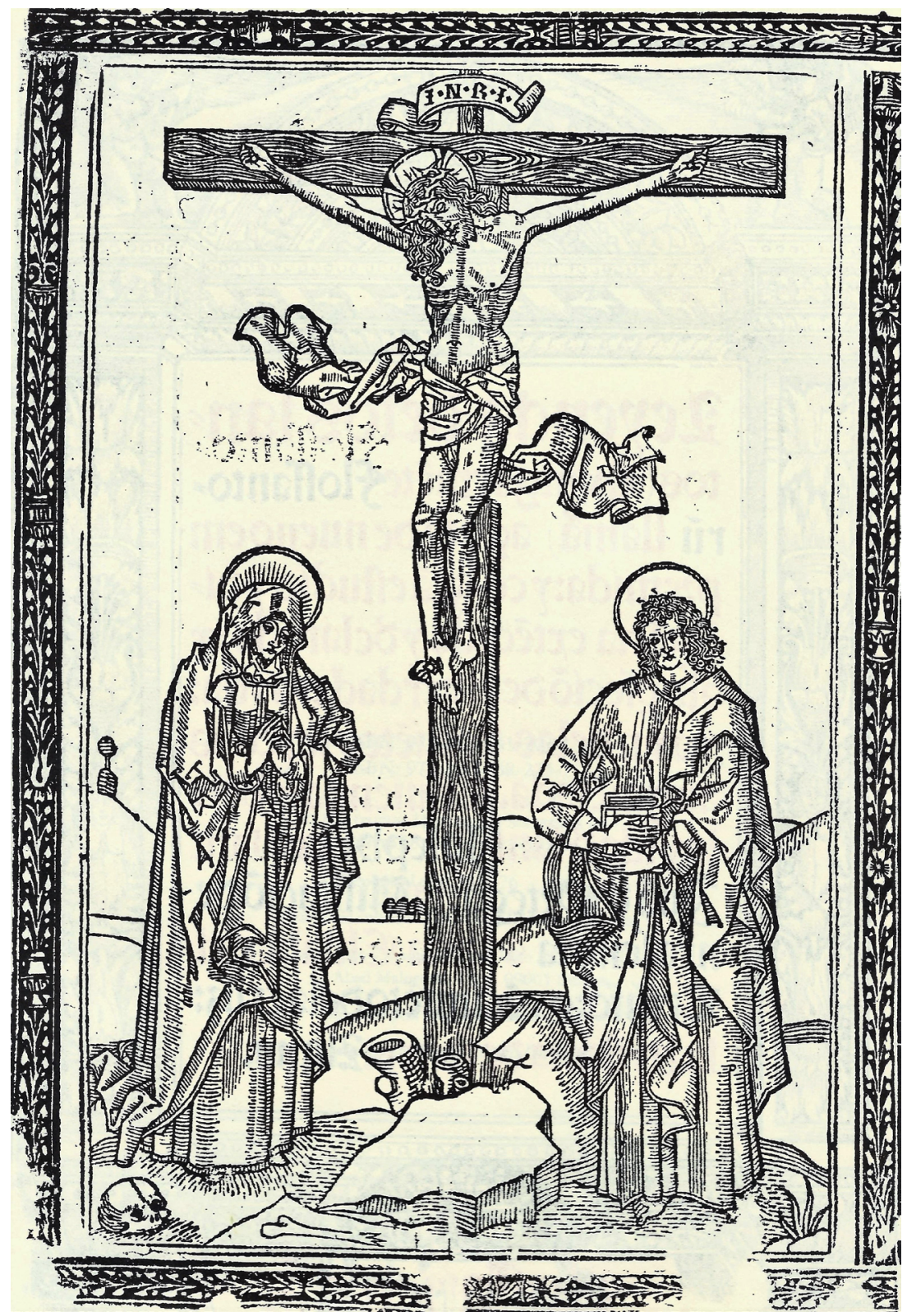

I8. Leyenda de los santos. Sevilla, Juan Varela, I520-I52I (?). Santuario de Loyola, 30-20 I9, fol. IV. 


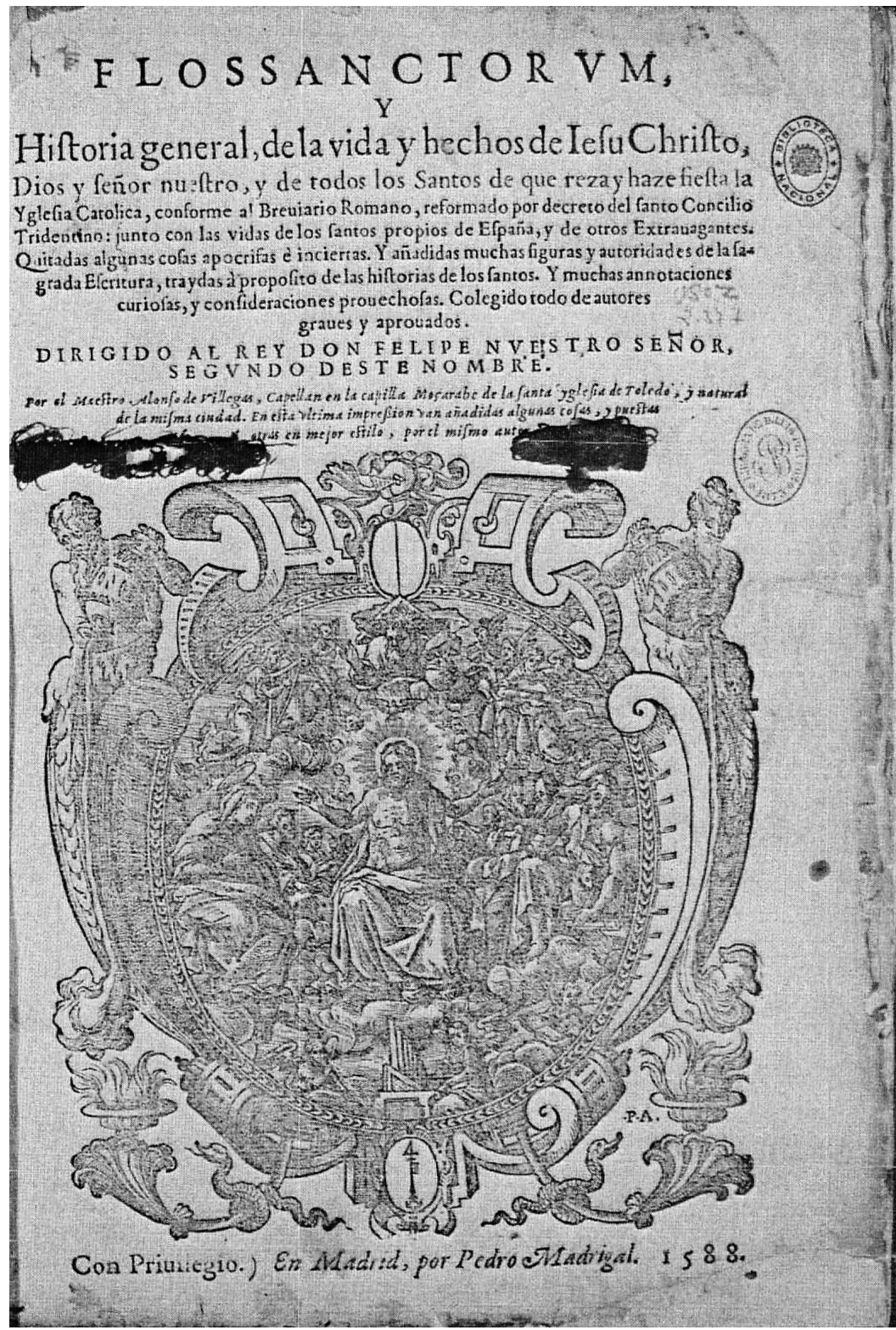

19. Alonso de Villegas, Flos sanctorum y historia general de la vida y hechos de Jesuchristo, Dios y Señor nuestro, y de todos los Santos. Vol. I, Madrid, Pedro Madrigal, 1588, portada. 


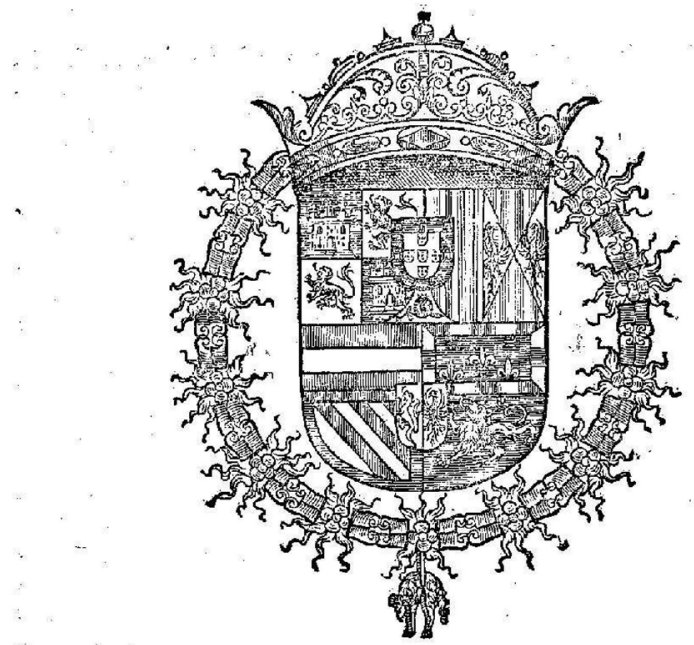

\title{
A L R E Y D O N F E I P E nueftro feñor, Segunido defte nombre.
}

\author{
El a Taepró Alonfo de Villegas.
} R $A N D E E S L A O B L I G A C I O Z$

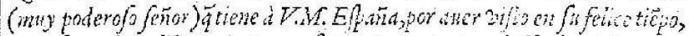

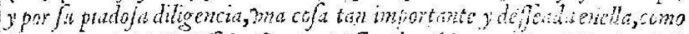

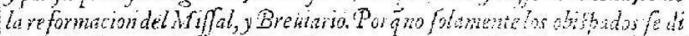

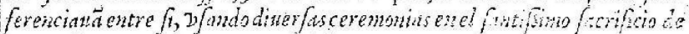

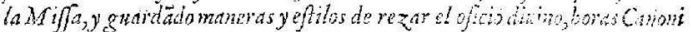

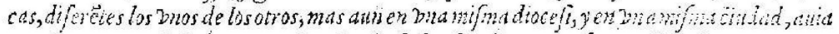

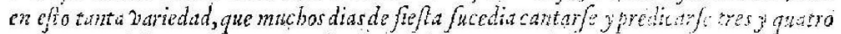

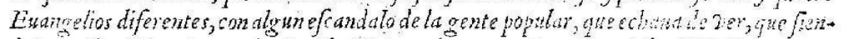

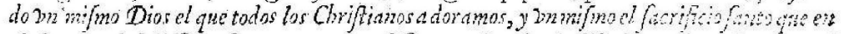

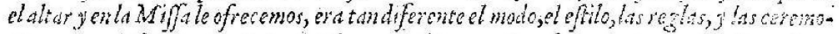

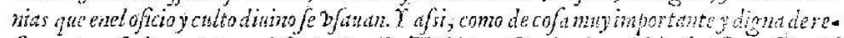

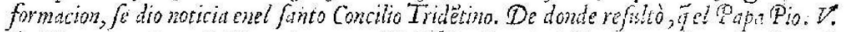

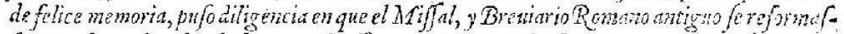

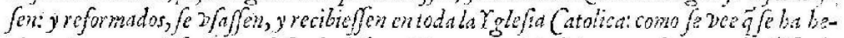

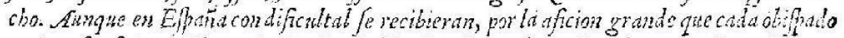

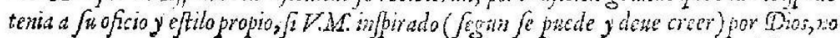
bobitiera

\section{(C) Biblioteca Nacional de España}

20. Alonso de Villegas, Flos sanctorum y historia general de la vida y hechos de Jesuchristo, Dios y Señor nuestro, $y$ de todos los Santos. Vol. I, Madrid, Pedro Madrigal, I588, dedicatoria. 


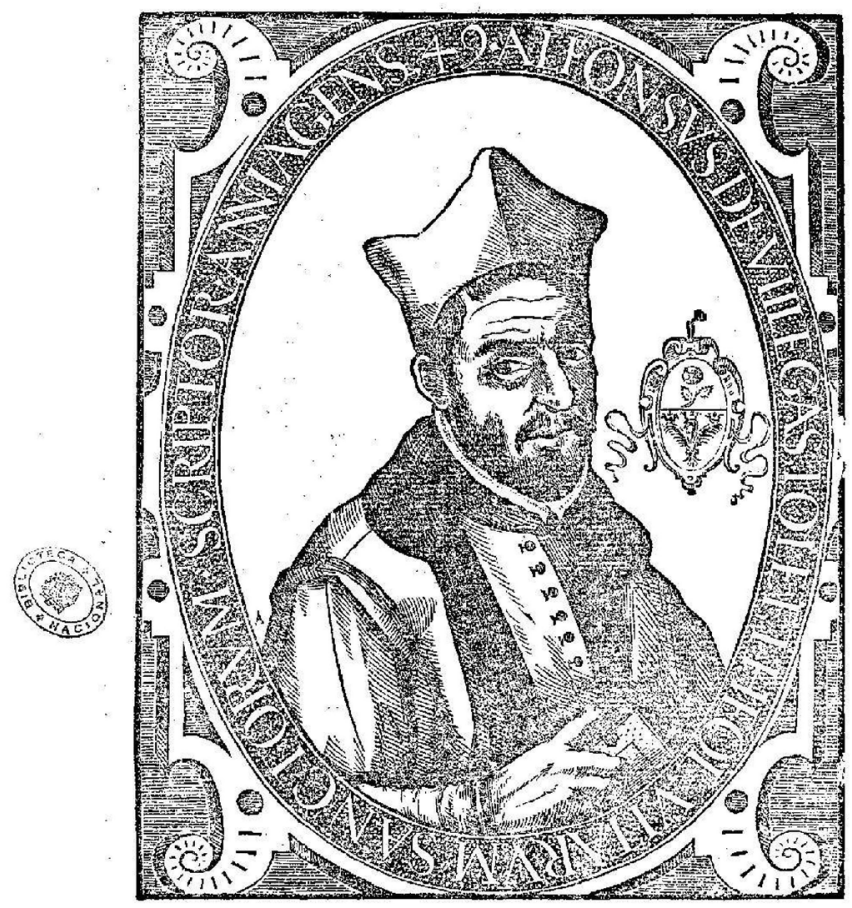

\title{
El Maeftro Alonfo de Villegas al Letor.
}

\begin{abstract}
Fin OR Aner fabido, Cliriftiano Letor, que efte Flos fandiorum fe ba impreffo 18. dinerfas bezes fin orden mio, yue las imprefiones falencax mucbos errores:

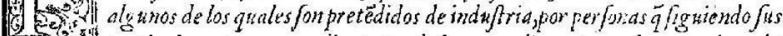

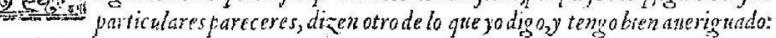

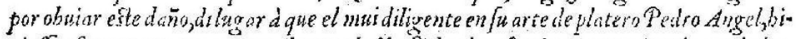

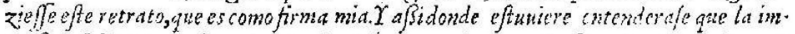

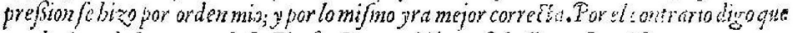

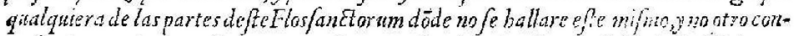
trabecbo por el, gue no fe tenga por mia, antes dewria enitar fe comoldecinga. Vale.
\end{abstract}

\section{Biblioteca Nacional de España}

2I. Alonso de Villegas, Flos sanctorum y historia general de la vida y hechos de Jesuchristo, Dios y Señor nuestro, y de todos los Santos. Vol. I, Madrid, Pedro Madrigal, I588, retrato. 


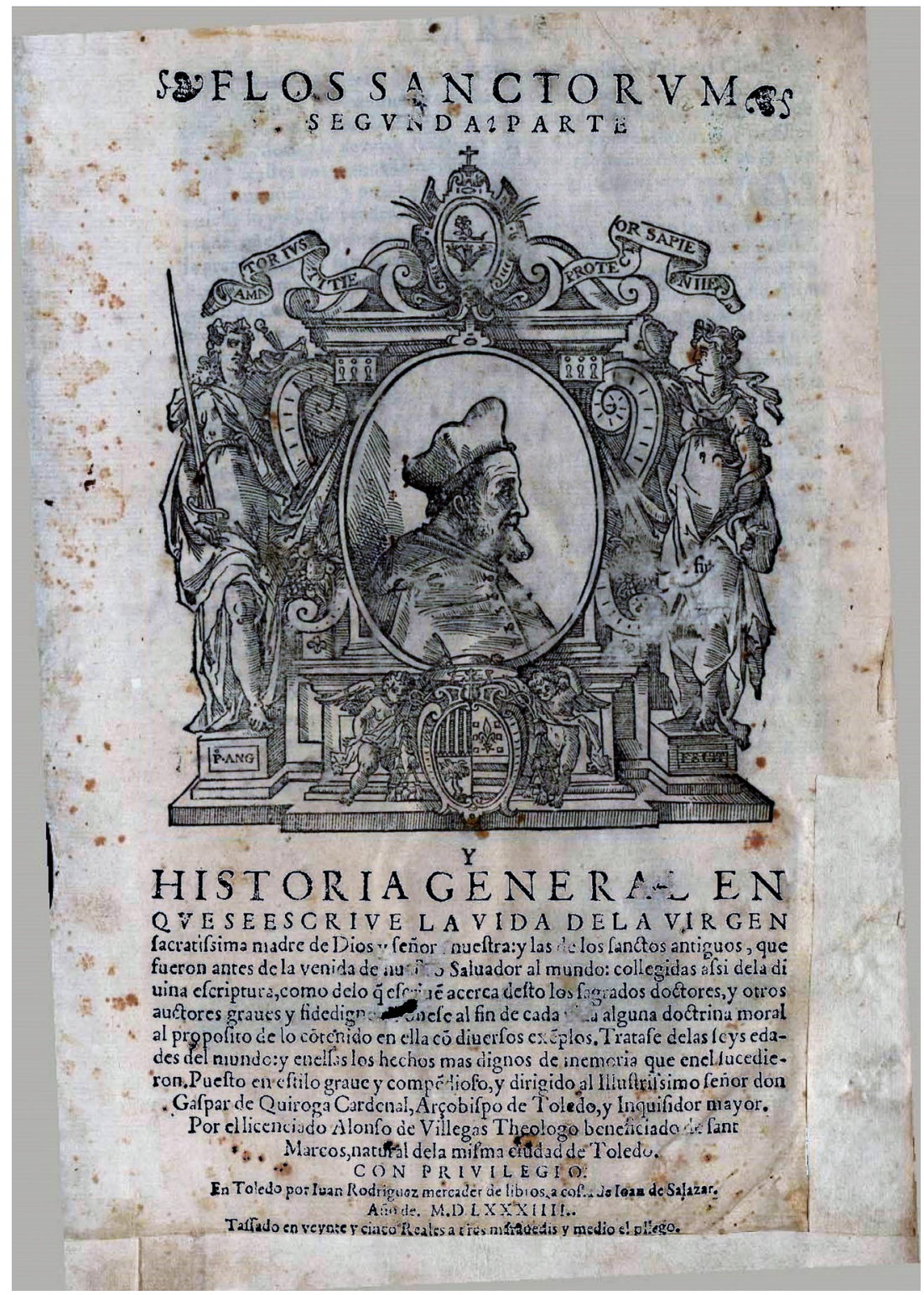

22. Alonso de Villegas, Flos sanctorum. Segunda parte y historia general en que se escrive la vida de la Virgen (...), y las de los sanctos antiguos, Toledo, Juan Rodríguez, I584, portada. 


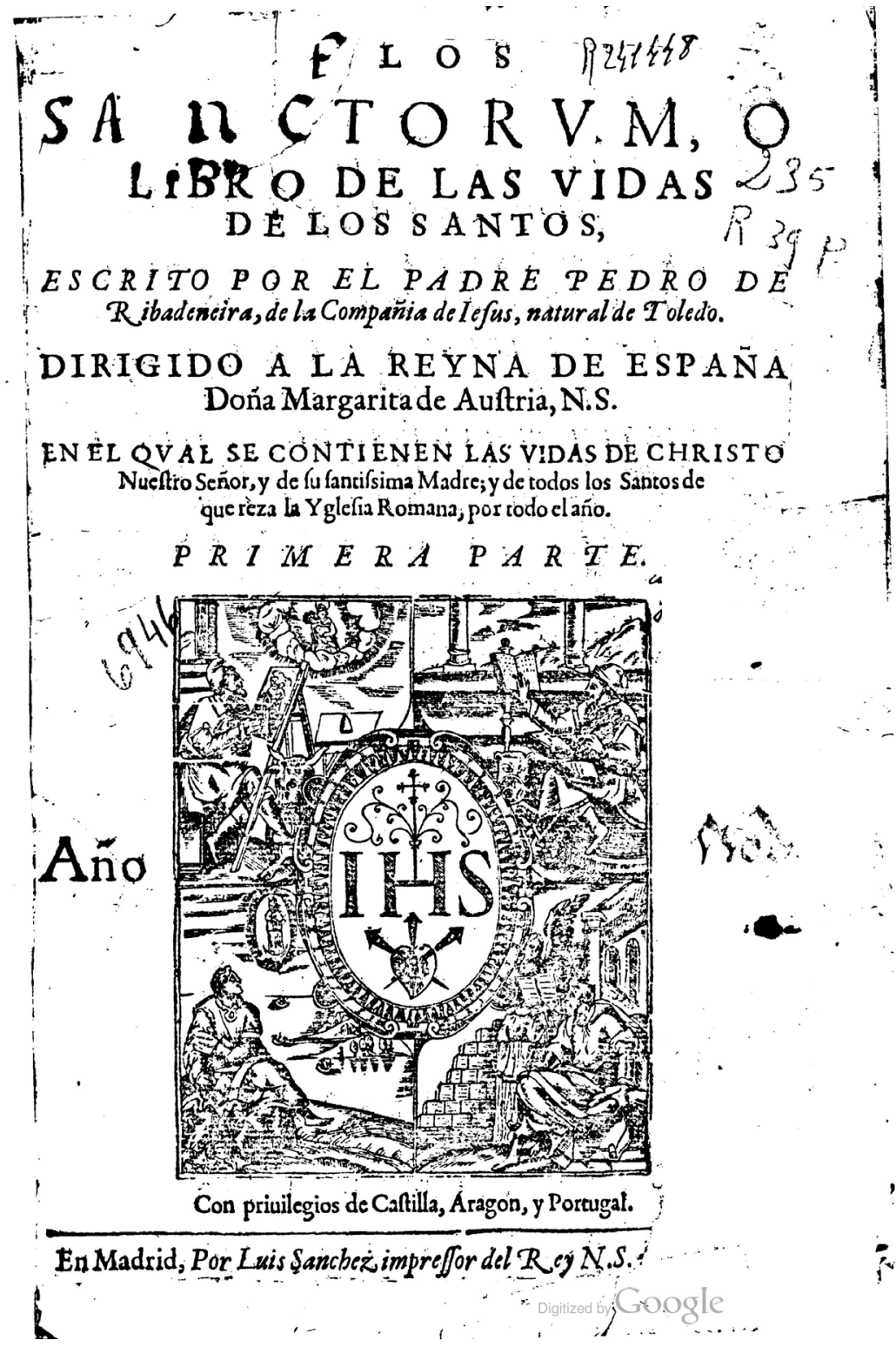

23. Pedro de Ribadeneira, Flos sanctorum, o libro de las vidas de los santos. Primera parte, Madrid, Luis Sánchez, I6I6, portada. 


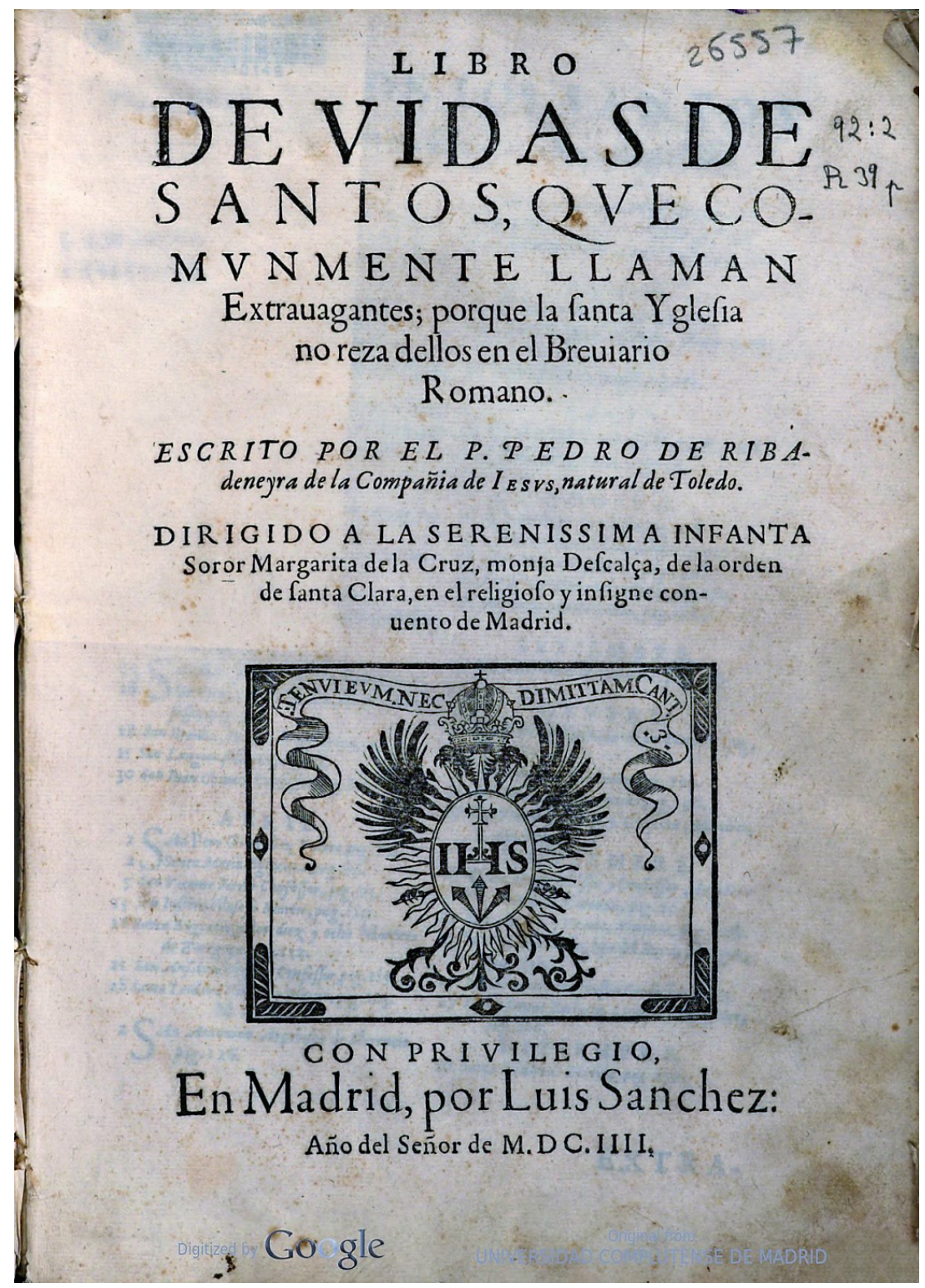

24. Pedro de Ribadeneira, Libro de vidas de santos, que comúnmente llaman Extravagantes, Madrid, Luis Sánchez, I604, portada. 


\section{Bibliografía}

\section{Santorales por orden cronológico}

Flos sanctorum copiado para Pedro Fernández de Velasco, primer Conde de Haro. Ms. 12689 de la Biblioteca Nacional de España (Madrid), primera mitad del siglo XV.

El flos santorun con sus ethimologías, Castilla (?), I472-I475 (?), Library of Congress (Washington), Incun.X/F.59.

Flos sanctorum copiado para Isabel la Católica. Ms. h-II-I8 de la Biblioteca de El Escorial, ca. 1488.

Pasión de Cristo, Preliminares a la Leyenda de los santos. Burgos, Fadrique de Basilea, I493 (?), ejemplar completo y exento en Boston Public Library, Q.403.88, ejemplar de otra edición del mismo impresor carente de los dos primeros folios y encuadernado en volumen facticio con la Leyenda de los santos en British Library (Londres), IB 53235.

Leyenda de los santos, Burgos, Juan de Burgos, 1497 (?), British Library (Londres), IB 53312.

Flos sanctorum, Zaragoza, Jorge Cocci, I516, Biblioteca Nacional de España (Madrid), R-23859.

Leyenda de los santos, Sevilla, Juan Varela, I520-I52I (?), Santuario de Loyola, 30-20 I9. Ed. Félix Juan Cabasés, Leyenda de los santos (que vulgarmente Flos Santorum llaman), Madrid, Universidad Pontificia de Comillas, 2007.

Villegas, Alonso de, Flos sanctorum y historia general de la vida y hechos de Jesuchristo, Dios y Señor nuestro, y de todos los Santos de que reza y haze fiesta la Iglesia Católica, conforme al Breviario Romano, reformado por decreto del Santo Concilio Tridentino, vol. I, Madrid, Pedro Madrigal, I588 (I ${ }^{\mathrm{a}}$ ed. I578).

Villegas, Alonso de, Flos sanctorum. Segunda parte y historia general en que se escrive la vida de la Virgen sacratíssima madre de Dios y Señora nuestra, y las de los sanctos antiguos que fueron antes de la venida de nuestro Salvador al mundo, Toledo, Juan Rodríguez, I584.

Ribadeneira, Pedro de, Flos sanctorum, o libro de las vidas de los santos, escrito por el padre Pedro de Ribadeneira, de la Compañía de Jesús, natural de Toledo. Dirigido a la reina de España doña Margarita de Austria. Primera parte, Madrid, Luis Sánchez, I6I6 (I a ed. I599).

Ribadeneira, Pedro de, Libro de vidas de santos, que comúnmente llaman Extravagantes, Madrid, Luis Sánchez, I604.

\section{Bibliografía}

Almeida, António José de, «Vidas e ilustrações das santas penitentes desnudas, no deserto e em peregrinação, no Flos Sanctorum de I5I3», Via Spiritus, I6, 2009, pp. I09-I58. 
Aragüés Aldaz, José, «El santoral castellano en los siglos XVI y XVII. Un itinerario hagiográfico», Analecta Bollandiana, II8, 2000, pp. 329-386.

-. «Para el estudio del Flos Sanctorum Renacentista (I). La conformación de un género", en Homenaje a Henri Guerreiro. La hagiografía entre historia y literatura en la España de la Edad Media y del Siglo de Oro, ed. Marc Vitse, Madrid/ Frankfurt, Universidad de Navarra / Iberoamericana / Vervuert, 2005, pp. 97-I47.

-. «Los flores sanctorum medievales y renacentistas. Brevísimo panorama crítico», en Literatura medieval y renacentista en España: líneas y pautas, eds. Natalia Fernández Rodríguez y María Fernández Ferreiro, Salamanca, La SEMYR, 20I2, pp. 349-36I.

-. «La difusa autoría del Flos sanctorum: silencios, presencias, imposturas», en El autor oculto en la literatura española: siglos XIV a XVIII, ed. Maud Le Guellec, Madrid, Casa de Velázquez, 20I4, pp. 2I-40.

-. «La Leyenda de los santos: orígenes medievales e itinerario renacentista», Memorabilia, I8, 2016, pp. I33-187.

Baños Vallejo, Fernando, La hagiografía como género literario en la Edad Media (Tipología de doce vidas individuales castellanas), Oviedo, Departamento de Filología Española, I989.

- Las vidas de santos en la literatura medieval española, Madrid, El Laberinto, 2003.

-. «Para Isabel la Católica: la singularidad de un flos sanctorum (ms. h.II.I8 de El Escorial)», en Los códices literarios de la Edad Media. Interpretación, historia, técnicas y catalogación, Salamanca, Instituto de Historia del Libro y de la Lectura, 2009, pp. I6I-I93.

-. «Vidas de santos en manos de nobles: mecenas y coleccionistas», en Estudios sobre la Edad Media, el Renacimiento y la Temprana Modernidad, eds. Francisco Bautista y Jimena Gamba, San Millán de la Cogolla, SEMYR-Cilengua, 20Io, pp. 6I-76.

-. "La transformación del flos sanctorum castellano en la imprenta», en Vides medievals de sants: difusió, tradició i llegenda, eds. Marinela Garcia Sempere y M. Àngels Llorca Tonda, Alicante, Institut Interuniversitari de Filologia Valenciana, 2012, pp. 65-97.

-. «La ilustración en las primeras ediciones peninsulares del flos sanctorum», en Actas del VI Congreso Internacional de la SEMYR, en prensa.

Carvajal González, Helena y Silvia González-Sarasa Hernáez, «Los Flos sanctorum: la impronta de la tradición manuscrita en la evolución de un producto editorial», en Literatura medieval y renacentista en España: líneas y pautas, eds. Natalia Fernández Rodríguez y María Fernández Ferreiro, Salamanca, La SEMYR, 20I2, pp. 433-442.

Chauchadis, Claude, «Paratexto y autoría en el flos sanctorum renacentista», en Paratextos en la literatura española (siglos XV-XVIII), eds. Ma Soledad 
Arredondo, Pierre Civil y Michel Moner, Madrid, Casa de Velázquez, 2009, pp. 307-319.

Civil, Pierre, "Flos Sanctorum et iconographie religieuse dans l'Espagne de la Contre-Réforme: le portrait de la Vierge», en D'un genre à l'autre. Renaissance et Siècle d'Or. Espagne-Italie-Portugal, eds. Monique Joly y Marie-Françoise Piejus = Les Langues Néo-Latines, 295, 1995, pp. II9-I39.

—. «Religiosité populaire et religiosité des élites à travers les Flos sanctorum de la fin du XVI ${ }^{\mathrm{e}}$ siècle», en Relations entre identités culturelles dans l'espace ibérique et ibéro-américain, vol. II, dir. Augustin Redondo, París, Presses de la Sorbonne Nouvelle $=$ Cahiers de l'UFR d'Études Ibériques et LatinoAméricaines, II, 1997, pp. 77-94.

Hernández Amez, Vanesa, Descripción y filiación de los flores sanctorum medievales castellanos, Tesis doctoral, Universidad de Oviedo, 2006.

Lyell, James P. R., La ilustración del libro antiguo en España, ed. Julián Martín Abad, Madrid, Ollero y Ramos, 1997.

Moreno Garrido, Antonio, «Las diferentes ediciones del Flos sanctorum, de Vega, Zaragoza, Cocci, I52I: análisis iconográficos», Seminario de Arte Aragonés, XXXIII, I98I, pp. 69-76. 